\title{
Karolina Łopacińska
}

Uniwersytet Ekonomiczny we Wrocławiu

Wydział Nauk Ekonomicznych

e-mail: lopacinska.karolina@gmail.com

\section{Innowacje proekologiczne w chińskim rolnictwie jako wyraz realizacji planu strategicznego na lata $2016-2020$}

Kody JEL: O13, Q1

Słowa kluczowe: rolnictwo, innowacje, nowe technologie, proekologia, plan strategiczny

Streszczenie. Celem artykułu jest przedstawienie kierunków planu strategicznego rządu Chin, zorientowanego na modernizację chińskiego sektora rolnego przez wdrażanie nowoczesnych rozwiązań i pogłębienie postępu technicznego, co z kolei pozwala na zwiększenie konkurencyjności podmiotów w tym sektorze. W artykule przedstawiono wdrażanie nowoczesnych technologii rolniczych, które pozwalają na produkcję przyjazną środowisku, jako wyraz kształtowania społecznej odpowiedzialności i świadomości ekologicznej producentów w chińskim sektorze rolno-spożywczym. Mają one na celu podniesienie jakości produktów rolnych w kontekście zwiększenia poziomu zaspokojenia potrzeb i zwiększenia bezpieczeństwa żywieniowego konsumentów. Rozważania zostały poparte przykładami rozwiązań wdrożonych przez chińskich producentów w wybranych obszarach tego sektora. W końcowej części przedstawiono wyniki i perspektywy dalszego rozwoju sektora rolnego w Chinach. Artykuł opiera się na analizie danych uzyskanych z raportów specjalistycznych instytutów badawczych i agencji doradczych, a także innych drugorzędnych źródeł informacji. 


\section{Wprowadzenie}

Chiny postrzegają wyżywienie ludzi jako najwyższy priorytet dla rozwoju gospodarczego i społecznego kraju. $Z$ tego względu rolnictwo jest uważane za sektor o znaczeniu kluczowym, a modernizacja rolnictwa ma kluczowe znaczenie dla zwiększenia jego zintegrowanej zdolności produkcyjnej, ustanawiając mechanizm, który zapewni długoterminowe bezpieczeństwo żywnościowe i promuje zrównoważony rozwój, który jest przyjazny dla środowiska.

Chociaż populacja Chińskiej Republiki Ludowej (1,409 miliarda) stanowi jedną piątą światowej populacji, to grunty orne w Chinach stanowią jedynie 5$7 \% \mathrm{w}$ skali globalnej. To właśnie ten niedobór gruntów ornych w połączeniu ze wzrostem liczby ludności spowodował, że rozwój innowacji w dziedzinie rolnictwa znalazł się na szczycie listy priorytetów chińskiego rządu, gdyż bez rozwiązania tego problemu Chiny, jako najbardziej zaludniony kraj na świecie, nie byłby w stanie iść do przodu i osiągać korzystnego tempa wzrostu (Jinyue, 2018).

Kluczowa rola modernizacji rolnictwa w obecnej polityce rządowej została podkreślona przez Prezydenta Chińskiej Republiki Ludowej, Xi Jinpinga, podczas 19. Kongresu Narodowego Komunistycznej Partii Chin, który odbył się w październiku 2017 roku. Należy jednak zauważyć, że osiągnięcie tego celu jest możliwe tylko dzięki zintensyfikowanym pracom badawczym i technologicznym w sektorze rolno-spożywczym (Zhang, 2017). Znalazło to również odzwierciedlenie w Trzynastym Pięcioletnim Planie Rozwoju Gospodarczego kraju. Zgodnie z postanowieniami planu za dwie główne ścieżki przyjęto: rozwój chińskiego rolnictwa i nauk przyrodniczych oraz pobudzanie innowacji technologicznych.

W nadchodzących latach Chiny skoncentrują się zatem przede wszystkim na ulepszeniu przemysłu high-tech w rolnictwie. Osiągnięcie tego celu wymaga wzmocnienia kluczowych obszarów, tj. związanych z: biotechnologią, inteligentnymi maszynami, nowymi materiałami rolnymi, nowoczesną produkcją żywności i ochroną rolno-środowiskową. Ponadto planowana jest regularna budowa parków naukowo-technologicznych i inkubatorów rolnych, co ma zachęcać do stosowania innowacji $\mathrm{w}$ celu poprawy jakości procesów, modeli biznesowych i obsługi klienta, a także rozwoju innowacyjnych firm high-tech w sektorze rolno-spożywczym.

Planuje się także rozwijać i wzmacniać współpracę międzynarodową w dziedzinie nauk rolniczych i technologii. W tym celu zostaną wykorzystane flagowe strategie chińskiego rządu, czyli Go Global i One Belt and One Road. Stworzy to bowiem szerszy zakres rozwoju rolnictwa i pełnego wykorzystania rynków, objętych przez te dwie inicjatywy, oraz zasobów, które wygenerują. To z kolei poprawi zdolność Chin do tworzenia innowacji w kluczowych obszarach rolnictwa. W ten sposób wzmocniona zostanie również międzynarodowa współpraca państw w zakresie podejmowania dwustronnych i wielostronnych badań 
oraz rozwoju technologii rolniczych (National People's Congress Of China, 2016).

Konieczne jest rozwijanie inwestycji infrastrukturalnych realizowanych w sektorze rolno-spożywczym, które prowadzą do poprawy efektywności, czasu inwestycji i kosztów dystrybucji, stymulując lokalne gospodarki przez zwiększenie popytu na produkty o wyższej wartości. Sieć dystrybucji łańcucha chłodniczego w całym kraju, która jest wciąż słabo rozwinięta, również wymaga intensywnego rozwoju.

Jednak osiągnięcie zrównoważonego rozwoju sektora rolno-spożywczego wymaga od chińskich przedsiębiorstw ciągłej aktualizacji wiedzy i wykorzystania nowoczesnych technologii. Wraz z szybkim rozwojem gospodarczym oraz postępem nauki i technologii zapotrzebowanie ludzi na żywność wykracza daleko poza proste zaspokojenie podstawowych potrzeb. Nic więc dziwnego, że obecnie w Chinach kładzie się nacisk na potrzebę wprowadzenia większej liczby innowacji w dziedzinie bezpieczeństwa żywności, inteligentniejszej produkcji i dystrybucji żywności, a także wdrażania nowych technologii na obszarach rolniczych (Xi, 2017). Doprowadziło to do stworzenia nowego terminu biznesowego - „technologia rolno-spożywcza”. Koncentruje się ona głównie na promowaniu rozwoju rolnictwa i przemysłu spożywczego przy użyciu nowych technologii i obejmuje m.in. prace nad znalezieniem lub stworzeniem substytutów żywności i nowych nasion, a także rozwój nowych rozwiązań dla technologii stosowanych w restauracjach, inteligentnych kuchniach, bezpieczeństwie żywności i agrotechnice.

Celem artykułu jest przedstawienie kierunków strategii Go Global ukierunkowanej na modernizację chińskiego sektora rolno-spożywczego przez wdrażanie nowoczesnych rozwiązań i pogłębienie postępu technologicznego, co z kolei pozwala na zwiększenie konkurencyjności podmiotów działających w tym sektorze.

\section{Kierunki modernizacji chińskiego rolnictwa}

Głównym celem, który Chiny będą starały się w następnych latach realizować, jest zbudowanie wydajnego i przyjaznego dla środowiska systemu rolnego, umożliwiającego oszczędzanie zasobów i utrzymanie podaży produktów rolnych, przy jednoczesnej poprawie sytuacji ekonomicznej rolników. Prognozy wskazują, że do 2020 roku produkcja zboża w Chinach wzrośnie o $50 \mathrm{mln}$ ton w porównaniu z rokiem 2015 i osiągnie $550 \mathrm{mln}$ ton. Jednocześnie spodziewany jest znaczny wzrost produktywności rolnictwa z 30 tys. juanów (w 2015 r.) do ponad 47 tys. juanów (w 2020 r.) (Demaree, 2016).

Aby osiągnąć wyznaczone cele, Chińska Rada Państwowa zainicjowała kampanię promocyjną dotyczącą reform w rolnictwie. Restrukturyzacja obej- 
muje: modernizację obecnej struktury plantacji i przemysłu rybnego, a także poprawę jakości hodowli zwierząt. Rząd podkreśla potrzebę zrównoważonego rozwoju rolnictwa i ulepszeń w dziedzinie technologii rolniczej. $Z$ tego powodu należy opracować odpowiednio dopasowany dla zasobów rolnych i pojemności każdego regionu plan maksymalizujący poziom osiąganej wydajności gruntów.

Dla zapewnienia jakości chińskiego produktu rolnego i bezpieczeństwa żywności planuje się stworzenie specjalnego systemu monitorowania produkcji rolnej w celu poprawy standardowej zdolności produkcyjnej.

Co więcej, chiński rząd deklaruje gotowość do wzmocnienia wsparcia finansowego przeznaczonego dla rolnictwa. Obejmuje ono optymalizację polityki $\mathrm{w}$ zakresie inwestycji prowadzonych $\mathrm{w}$ dziedzinie rolnictwa oraz poprawę w obszarach: wsparcia kredytowego, dopłat rolnych, ubezpieczeń rolnych i regulacji rynku dotyczących użytkowania gruntów i produktów rolnych (Demaree, 2016).

\section{Innowacyjne rozwiązania w dziedzinie rolnictwa}

Aby osiągnąć cel strategiczny, tj. modernizację rolnictwa i bardziej racjonalną gospodarkę zasobami oraz poprawę stanu środowiska, zasadnicze znaczenie ma dalsze promowanie naukowych i technologicznych innowacji w tym sektorze. Obecnie Chiny, produkując aż 25\% światowej żywności dla około $20 \%$ światowej populacji, zakończyły przemianę z kraju odbiorcy pomocy żywnościowej do dawcy tej pomocy.

W 2016 roku został zatwierdzony przez Radę Państwową Komitetu Centralnego CPC plan Outline for Healthy China 2030. Głównym jego celem jest poprawa systemu norm bezpieczeństwa żywności i osiągnięcie zgodności norm bezpieczeństwa żywności stosowanych w Chinach z międzynarodowymi standardami. Ciągłe monitorowanie, doskonalenie i ocena potencjalnych zagrożeń dla bezpieczeństwa żywności mają być zasadą dochodzenia do tego celu. W ten sposób chiński rząd chce osiągnąć pełną kontrolę ryzyka w obszarze bezpieczeństwa żywnościowego do 2030 roku (Feng, 2018).

W ciągu ostatnich pięciu lat Chiny dokonały wielu znaczących osiągnięć w nowoczesnej produkcji rolnej. Zdolność produkcyjna chińskiego rolnictwa osiągnęła wyższy poziom, wyrażony wolumenem produkcji ziarna wynoszącym $620 \mathrm{mln}$ ton w 2015 roku, przy jednoczesnym wzroście dochodu rolnika do 1739 USD, co oznacza wyższą stawkę niż produkt krajowy brutto lub dochód osiągnięty przez mieszkańców miasta na jednego mieszkańca. Do tego wzrostu niewątpliwie przyczyniła się realizacja osiągnięć naukowych i technologicznych. Oznacza to przejście od modelu biznesowego w rolnictwie i produkcji roślinnej opartego na zasobach do modelu bazującego na nauce i technologii. Pozwoliło to na znaczny wzrost poziomu mechanizacji w rolnictwie, który obejmował $63 \%$ procesów produkcyjnych (sadzenie i zbiór), a także skuteczne nawadnianie gruntów rolnych, obejmujące $52 \%$ gruntów rolnych. W rezultacie wdrożenie nowych 
modeli gospodarki rolnej przyczyniło się do zrównoważonego wzrostu potencjału rolnictwa i obszarów wiejskich.

Oceniając innowacje w dziedzinie rolnictwa i zrównoważonego rozwoju w Chinach, można zauważyć postępy w takich obszarach jak: hybrydowa hodowla ryżu, produkcja i genetyczna poprawa drobnych zbóż, produkcja roślin strączkowych, badania i produkcja nasion rzepaku, ewolucja i udomawianie bawełny, innowacje w systemie upraw, zarządzanie agronomią ryżu, badania genetyczne oparte na genomice i mapowanie QTL.

Jako jeden z głównych chińskich wkładów w naukę o uprawach należy uznać osiągnięcia w produkcji ryżu, gdyż ryż hybrydowy zasadzono na ponad 50\% ziemi ryżowej w Chinach. Dlatego oczekuje się, że ryż ten będzie nadal przyczyniał się do światowego bezpieczeństwa żywnościowego. Poza głównymi zbożami, takimi jak: ryż, kukurydza i pszenica, warto zauważyć, że kilka mniejszych zbóż, takich jak: berberys, sorgo, jęczmień, owies i proso, ma znaczny udział w chińskim rolnictwie, wzbogacając w ten sposób zasoby żywności w Chinach. Ich wysoka tolerancja na suszę i wysoka efektywność wykorzystania nawozów stwarza bowiem nowe możliwości rozwoju przyjaznych dla środowiska upraw i bardziej zróżnicowanego zaopatrzenia ludzi i zwierząt w żywność (Xu, Li, Wan, 2017).

Z uwagi na szybsze niż wskazuje średnia światowa ocieplenie klimatu w Chinach niezwykle ważne są innowacje prowadzące do rozwoju nowych odmian upraw, ich optymalizacji oraz dostosowania regionu uprawy. Będzie to jednak zależało od konkretnych regionów uprawy, pór roku i samych upraw. Konieczne jest zatem inwestowanie w inteligentną politykę rolną w zakresie klimatu, wykorzystywanie nowej wiedzy i technologii, a także w rozwój infrastruktury celem zwiększenia odporności systemu upraw (Xu, Li, Wan, 2017; Li, Liu, Min, 2011; Cyranoski, 2018).

\section{Inicjatywy wspierające rozwój rolnictwa ekologicznego}

Ważnym przejawem promocji zrównoważonego rolnictwa w Chinach było wprowadzenie w 2015 roku wartego 200 mln USD projektu ekologicznego rolnictwa. Realizacja jego założeń umożliwiła rolnikom z pięciu różnych prowincji w Chinach korzystanie z rządowych dotacji i wsparcia technicznego. Jak wynika z badania przeprowadzonego w 2010 roku, rolnictwo było główną przyczyną zanieczyszczenia wody w Chinach, ponieważ szacuje się, że tylko ok. 30-40\% zastosowanych pestycydów spełniało zamierzone funkcje, podczas gdy pozostałe zostały uwolnione do środowiska lub wpłynęły na produkty rolne w sposób zagrażający bezpieczeństwu żywności. W związku z tym pojawiła się silna potrzeba zmniejszenia ilości stosowanych pestycydów i nawozów. W rezultacie w 470141 chińskich wiejskich gospodarstw domowych zainstalowano biogeneratory oraz 
odnowioną kuchnię i toaletę. Celem tej inicjatywy było zmniejszenie zanieczyszczenia powietrza $\mathrm{w}$ pomieszczeniach, zaoszczędzenie czasu na zbieranie drewna opałowego i gotowanie na nim, zwiększenie dochodów przez zmniejszenie wydatków na węgiel i nawozy, poprawę warunków sanitarnych i środowiska, zmniejszenie emisji gazów cieplarnianych i poprawę ogólnej jakości życia mieszkańców. Projekt skupił się również na pomocy w przekształcaniu odpadów zwierzęcych w paliwo do użytku domowego zamiast zanieczyszczania lokalnych zasobów wody. W niektórych obszarach drony i inne zaawansowane technologicznie metody uzupełniają profesjonalne usługi zarządzania szkodnikami. Projekt został wsparty przez Bank Światowy (The World Bank, 2016).

Należy podkreślić, że realizując politykę proekologiczną, tylko w pierwszej połowie 2017 roku chiński rząd uruchomił prawie 8000 projektów związanych z oczyszczaniem wody, o wartości 667,5 mld RMB (100 mld USD) (Blenkinsop, 2017).

Ponadto biorąc pod uwagę negatywny wpływ stosowania nawozów na środowisko (zanieczyszczenie wody, zakwaszenie gleby i przyczynianie się do globalnego ocieplenia), Chiny koncentrują się na promowaniu świadomości społecznej wśród obywateli poprzez pobudzanie ich uczestnictwa w ochronie środowiska na obszarach wiejskich.

Obecnie w całym kraju powstaje ponad 260 krajowych parków technologicznych zajmujących się rolnictwem i naukami ścisłymi oraz promujących nowe technologie rolne w dziedzinie wydajnego gospodarowania wodą i hodowli zwierząt, które mają służyć częściowo jako prezentacja technologii, a częściowo jako pilotażowe gospodarstwa badawczo-rozwojowe. Niektóre z tych podmiotów zapewniają dotacje dla przedsiębiorców. Podkreśla się również rolę uniwersytetów rolniczych, które tworzą przestrzeń dla startujących zespołów studentów i absolwentów. Jako przykład można wskazać tzw. Cyb-Bot, czyli firmę zajmującą się robotyką i automatyką, która otrzymała pieniądze z Chińskiego Funduszu Uniwersyteckiego.

Efekty zaangażowania sektora komercyjnego $\mathrm{w}$ proces przekształcania w faktyczne przedsiębiorstwa spożywcze są już widoczne. Dowodem tego jest 4000 firm typu start-up uruchamianych każdego dnia. Należy jednak podkreślić, że tzw. start-upy żywnościowe stanowią jedynie niewielką ich część. Najbardziej aktywne w tym obszarze są tzw. firmy „online-to-offline” (O2O), takie jak: Ele.me (dostawca żywności B2C o wartości 4,5 mld USD) i Meicai (dostawca produktów spożywczych B2B o wartości 2 mld USD) (UHY, 2018).

Chociaż chińskie inwestycje w sektorze rolno-spożywczym nie osiągnęły jeszcze tempa podobnego jak w innych częściach świata, należy się spodziewać, że w końcu przyspieszą, gdyż młode, niedoinwestowane firmy na rynku wykazują potencjał rozwojowy, a tworzenie nowych marek żywności jest dobrym kierunkiem inwestycji, który napędza chińską konsumpcję. Tworzenie zdrowego 
ekosystemu firmy jest zgodne z założeniami polityki modernizacji rolnictwa, ale wymaga odpowiednich inwestorów, mentorów, a przede wszystkim wsparcia rządowego (Bites, 2016).

Należy podkreślić, że dążenia Chin do wdrożenia rolnictwa ekologicznego w ich systemie rolniczym są wspierane nie tylko przez rząd, ale także przez samych Chińczyków. Doskonałym przykładem takich działań jest inicjatywa, którą podjęto w 2005 roku w China Agricultural University w Pekinie i realizowano do roku 2015. Celem tej inicjatywy, rozpoczętej przez Fusuo Zhanga, profesora żywienia roślin i dziekana Kolegium Zasobów i Nauk o Środowisku oraz jego współpracowników, było odkrycie najbardziej zrównoważonych lokalnych praktyk rolniczych odpowiednich dla każdego regiou Chin, które następnie zastosowano w setkach chińskich gospodarstw. W wyniku tej inicjatywy prawie $21 \mathrm{mln}$ rolników zmieniło dotychczasowe praktyki, przyjmując nowoczesne, oparte na zmniejszeniu zużycia nawozów (o 1,2 $\mathrm{mln}$ ton) rozwiązania w zarządzaniu glebami i wybierając bardziej odpowiednie nawozy dla miejscowych gleb. Przyczyniło się to do zwiększenia zbiorów, gdyż średnie plony ryżu, kukurydzy i pszenicy wzrosły o ponad $10 \% \mathrm{w}$ porównaniu do wcześniej stosowanych konwencjonalnych metod uprawy (China persuades..., 2018). Spodziewając się, że światowe zapotrzebowanie na żywność podwoi się w 2050 roku, w porównaniu z 2005 rokiem, naukowcy mają nadzieję, że wyniki tej inicjatywy będzie można zastosować również $\mathrm{w}$ innych krajach na całym świecie.

Ponadto ma zostać uruchomiony system wspólnego majątku zbiorowego na wsi, który będzie oferować akcje i dywidendy mieszkańcom obszarów wiejskich w Chinach. Aby było to jednak możliwe, konieczna jest poprawa systemu zarządzania rolnictwem. Dlatego zgodnie z założeniami planu władze zachęcają wiodące firmy w kraju do zaangażowania i włączenia mieszkańców wsi do realizacji tego celu. Podkreśla się, że utrzymanie środowiska rolnego ma kluczowe znaczenie dla rozwoju chińskiego rolnictwa. W związku z tym motywuje się obywateli Chin do ograniczenia stosowania nawozów i pestycydów oraz promowania bezpiecznego usuwania odpadów rolniczych, a tym samym do ochrony krajowych gruntów ornych, lasów i obszarów trawiastych, a także zasobów wody oraz ryb (Demaree, 2016).

\section{Aktualne osiągnięcia Chin w dziedzinie nauk rolniczych i technologii}

Postępy Chin w dziedzinie nauk rolniczych i technologii można podsumować w trzech punktach. Po pierwsze i przede wszystkim znacznie wzrosła zdolność do innowacji w dziedzinie rolnictwa. Uruchomienie platform badawczych dla genomiki funkcjonalnej, proteomiki, metabolizmu i innych technik molekularnych stworzyło podstawę do udoskonalenia ważnych cech agronomicznych, takich jak wydajność, jakość i odporność na stres biotyczny i abiotyczny, przyczyniając się $\mathrm{z}$ kolei do rozwoju teorii i poprawy metod uprawy. Ponadto poczyniono postępy 
w wyjaśnianiu mechanizmów funkcjonalnych składników terapeutycznych, co znacznie przyspieszyło odkrycie leków hodowlanych.

Po drugie, przełom dokonał się w kluczowych technologiach branżowych. Budowa platform doboru genomu $\mathrm{z}$ wykorzystaniem inżynierii komórek i informatyki hodowlanej pobudziła bowiem rozwój nowoczesnego przemysłu nasiennego. Z kolei przełom w zakresie technik przetwarzania, takich jak wydajne, automatyczne pobieranie i separacja produktów rolnych, a także przyjazne dla środowiska i niskoenergetyczne technologie suszenia, przyczynił się do rozwoju przemysłu spożywczego.

Po trzecie, innowacje techniczne znacznie poprawily wykorzystanie zasobów rolnych. Stworzenie teorii i metod oszczędzania wody i dystrybucji roślin o wysokiej wydajności i lepszej jakości przyczyniło się do opracowania zintegrowanego systemu technologicznego dla rolnictwa w regionach suchych i półsuchych. Technologia ściółkowania słomy ryżowej stosowana w południowych regionach górskich, w tym w prowincjach Yunnan i Guizhou, zmniejszyła straty wody i gleby na zboczach o $70 \%$ oraz zwiększyła wydajność gleby o $20 \%$ (Xu, Li, Wan, 2017).

Rozwój nowych technologii internetowych, takich jak bezprzewodowe sieci czujników, komunikacja i przetwarzanie w chmurze, inteligentne przetwarzanie informacji przyczynia się do stworzenia kompleksowych systemów śledzenia produkcji i konsumpcji najważniejszych produktów rolnych. Duże kombajny $\mathrm{i}$ inteligentne technologie, takie jak te wspierane przez system nawigacji satelitarnej Beidou, zrewolucjonizowały przemysł maszyn rolniczych.

\section{Współpraca Chin i krajów OECD w zakresie modernizacji rolnictwa}

Warto podkreślić, że dla osiągnięcia optymalnego rozwoju handlu produktami rolnymi dąży się do rozwijania współpracy zewnętrznej chińskiego przemysłu rolnego. Znajduje to zwłaszcza odzwierciedlenie w stałej współpracy Państwa Środka z krajami OECD w kwestiach związanych z rolnictwem, która została pogłębiona w 2016 roku. W ciągu ostatnich lat obie strony wspólnie podejmowały wysiłki na rzecz połączenia wdrażanych polityk w celu wzmocnienia systemu innowacji w rolnictwie, zwiększenia tempa wzrostu wydajności i dywersyfikacji źródeł zaopatrzenia w żywność przez większą integrację rynków krajowych i międzynarodowych rynków rolno-spożywczych.

Od 2005 roku Chiny uczestniczą w corocznej ewaluacji OECD w zakresie monitorowania i oceny polityki rolnej. Stanowi to unikalne źródło obiektywnych i przejrzystych informacji w 50 krajach, które tworzą większość globalnej wartości dodanej w rolnictwie, oferując również szeroką perspektywę dotyczącą rozwoju polityki rolnej. Ponadto w październiku 2017 roku OECD i MOA współorganizowały coroczne warsztaty na temat polityki handlowej i rolno-spożywczej, które odbyły się w Pekinie. 
Należy zaznaczyć, że w 2018 roku zostanie opublikowane sprawozdanie na temat innowacji, produktywności rolnej i zrównoważonego rozwoju w Chinach, opracowane wspólnie przez Chiny i OECD, we współpracy z chińskim Development Research Center of the State Council (DRC) oraz udziałem MOA, Ministerstwa Finansów Chińskiej Republiki Ludowej (MOF), MOST oraz NDRC.

Chiny i OECD współpracują ponadto z Chinese Academy of Agricultural Sciences (CAAS) nad opracowaniem rocznej prognozy rolnej OECD-FAO, która jest nieocenioną publikacją, dostarczającą szczegółowych prognoz średniookresowych perspektyw ważnych towarów w głównych gospodarkach światowych.

W lutym 2018 roku OECD i FAO zorganizowały wspólne spotkanie w celu inauguracji wdrożenia pilotażowego programu Wytycznych OECD-FAO w sprawie Odpowiedzialnych Łańcuchów Dostaw Rolniczych. Była to odpowiedź na wezwanie ministrów rolnictwa państw G20 do promowania odpowiedzialnych inwestycji rolnych. OECD z zadowoleniem przyjmuje chińskie firmy działające w łańcuchu wartości rolniczych, aby uczestniczyć w tym programie, i jest gotowa zapewnić wsparcie swoim doświadczeniem politycznym i praktyką w tej dziedzinie (OECD/FAO..., 2017).

\section{Podsumowanie}

Chiny stoją obecnie przed ogromnymi wyzwaniami związanymi z przekształceniem sektora rolno-spożywczego z systemu tradycyjnego w nowoczesny system oparty na wdrażaniu nowych technologii, zapewniających wysoką wydajność, bezpieczeństwo żywnościowe i ochronę środowiska naturalnego. Wymaga to jednak holistycznego podejścia, obejmującego wymiar technologiczny, ekonomiczny i społeczny. Aby sprostać tym wyzwaniom, należy zintensyfikować badania nad kluczowymi technologiami produkcji: nasion, leków, pasz i sprzętu rolniczego następnej generacji. Konieczne jest również szerokie wykorzystanie postępów w dziedzinie technologii informacyjnej, która wspiera modernizację procesów rolniczych. Nie można jednak zapominać, że Chiny wciąż znajdują się w krytycznym punkcie transformacji gospodarczej. Zdolność produkcyjna rolnictwa nadal nie jest stabilna, a wsparcie nauki i technologii nie jest jeszcze wystarczające, dlatego powinno się intensyfikować wysiłki w celu jego stałego zwiększania.

\section{Bibliografia}

Bites, B. (2016). China is Ready for an Agri-Food Revolution. Pobrano z: https://agfundernews. $\mathrm{com} /$ china-ready-agri-food-revolution.html (6.04.2018).

Blenkinsop, Ph. (2017). China launches 8,000 water clean-up projects worth $\$ 100$ billion in first half of 2017. The Thomson Reuters. Pobrano z: https://www.reuters.com/article/us-chinapollution-water/china-launches-8000-water-clean-up-projects-worth-100-billion-in-first-ha lf-of-2017-idUSKCN1B4090 (6.04.2018). 
Cyranoski, D. (2018). Millions of Chinese farmers reap benefits of huge crop experiment. Pobrano z: https://www.nature.com/articles/d41586-018-02792-7 (5.04.2018).

Demaree, H. (2016). China plans to promote modern agriculture. World Grain News. Pobrano z: www.world-grain.com/articles/news_home/World_Grain_News/2016/10/China_plans_to_ promote_modern.aspx $?$ ID $=\{8$ CF58542-1A75-426D-BFE6-54E18792DFA1 $\} \&$ cck $=1$ (6.04.2018).

Feng, C. (2018). Exploring Agri-Food Tech Opportunities in China. Pobrano z: https://www.startupbootcamp.org/blog/2018/01/exploring-agri-food-tech-opportunitieschina/ (3.04.2018).

China persuades millions to adopt eco-friendly farming (2018). Nature. International journal od science. Pobrano z: https://www.nature.com/articles/d41586-018-02829-x (7.04.2018).

Jinyue, F. (2018). Exploring Agri-Food Tech Opportunities in China. Pobrano z: https://www.star tupbootcamp.org/blog/2018/01/exploring-agri-food-tech-opportunities-china/ (12.03.2018).

Li, W., Liu, M., Min, Q. (2011). China's Ecological Agriculture: Progress and Perspectives. Journal of Resources and Ecology, 2 (1), 1-7.

National People's Congress Of China. (2016). China's NPC approves 13th Five - Year Plan (Issue 1). China: ThePeople's Congresses Journal. Pobrano z: www.npc.gov.cn/npc/zgrdzz/site1/ 20160429/0021861abd66188d449902.pdf (3.04.2018)..

OECD-FAO Agricultural Outlook 2017-2026. (2017). OECD Publishing. Paris. Pobrano z: http://dx.doi.org/10.1787/agr_outlook-2017-en (12.03.2018).

The World Bank (2016). China Eco-Farming Project Turns Wastes into Clean Fuel. Pobrano z: www.worldbank.org/en/results/2016/07/05/china-eco-farming-project-turns-wastes-intoclean-fuel (4.04.2018).

UHY (2018). Chinese lead global growth in new start-ups but economic slowdown threatens business creation. Pobrano z: www.uhy.com/chinese-lead-global-growth-in-new-start-upsbut-economic-slowdown-threatens-business-creation/ (3.04.2018).

Xi, J. (2017). Full text of Xi Jinping's report at 19th CPC National Congress. Pobrano z: www.chinadaily.com.cn/china/19thcpcnationalcongress/2017-11/04/content_34115212.htm (4.04.2018).

Xu, Y., Li, J., Wan, J. (2017). Agriculture and crop science in China: Innovation and sustainability. The Crop Journals, 5 (2), 95-99. Pobrano z: https://www.sciencedirect.com/science/ article/pii/S2214514117300144. (3.04.2018).

Zhang, Y. (2017). Rural vitalization strategy, timeline unveiled. Pobrano z: www.china daily.com.cn/a/201712/30/WS5a46c34aa31008cf16da44fa.html (3.04.2018).

\section{Eco-friendly Innovation in Chinese Agriculture as an Expression of the Implementation of the Strategic Plan for 2016-2020}

Keywords: agriculture, innovation, new technologies, proecology, strategic plan

Summary. The objective of the paper is to present the directions of the strategic plan of the Chinese government, focused on the modernization of the Chinese agricultural sector by implementing modern solutions and deepening technical progress, which in turn allows increasing the competitiveness of entities in this sector. The paper presents the implementation of modern agricultural technologies that allow for environmentally friendly production as an expression of shaping the social responsibility and ecological awareness of producers in the Chinese agricultural sector. They are aimed at improving the quality of agricultural products in the context of increasing the level of meeting the customers' needs and increasing their nutritional safety. The considerations are supported by examples of solutions implemented by Chinese producers in selected areas of the analysed 
sector. In the final part the results and prospects for further development of the agricultural sector in China have been presented. The paper is based on the analysis of data obtained from reports of specialist research institutes and consultancy agencies, as well as other secondary sources of information.

Translated by Karolina Łopacińska

\section{Cytowanie}

Łopacińska, K. (2018). Innowacje proekologiczne w chińskim rolnictwie jako wyraz realizacji planu strategicznego na lata 2016-2020. Marketing i Zarzadzanie, 3 (53), 109-119. DOI: 10.18276/miz.2018.53-10. 